OnLine Journal of Biological Sciences 7 (1): 12-17, 2007

ISSN 1608-4217

(C) 2007 Science Publications

\title{
Study of Benthic Fauna in the Discharge Lagoon of a Shrimp Farm With Special Emphasis on the Polychaetes
}

\author{
Luis Rafael Martínez Córdova and Luis Fernando Enríquez Ocaña \\ Departamento de Investigaciones Científicas y Tecnológicas de la Universidad de Sonora \\ Rosales y Blvd. Luis Encinas, Apdo Postal 1819, c.p. 83000, Hermosillo, Sonora, México
}

\begin{abstract}
A study of benthic fauna, with special emphasis on polychaetes, was made in the discharge lagoon of an experimental shrimp farm and a pond of the farm. The discharge lagoon was divided into three sections and stocked with shrimp at low density $(6 \mathrm{Pl} / \mathrm{m} 2)$. Neither formulated feed nor fertilization was used in these sections. The control pond was stocked with shrimp at high density (32 $\mathrm{Pl} / \mathrm{m} 2$ ). The pond was fertilized and fed with a commercial shrimp diet. Enclosures of $4 \mathrm{~m}^{2}$ were made in the sections and control ponds with plastic nets to exclude shrimp. Water quality parameters (temperature, salinity, dissolved oxygen, $\mathrm{pH}$ and organic matter) and the nutrients (N-NO2, N-NO3, TAN and P-PO4), were recorded during the study. Abundance and composition of benthic fauna were recorded biweekly in sections and pond. Significant differences in nutrients and organic matter were found among control pond and the discharge sections, with the highest values in the pond. The main benthic groups collected during the study were Chironomidae insect larvae, polychaete worms (Polydora socialis), gammarid crustaceans and gasteropods (Cerithidea sp). Total abundance of benthic organisms was greater in the discharge sections (5657 to 6202) compared with the control pond (5336). The abundance of polychaetes showed the same tendency (2318 to 2681 versus 1697). Total benthic abundance was always lower in sections and pond than in the respective enclosures (6882 to 7606 organisms). The same pattern was found for polychaetes abundance (3386 to 4006 organisms). Temporal variation of polychaetes abundance was mainly related to shrimp predation as confirmed by the more abrupt abundance decline in pond as compared to sections and in pond and sections as compared to the respective enclosures.
\end{abstract}

Key words: Benthic fauna, polychaeta, shrimp, Litopenaeus vannamei

\section{INTRODUCTION}

Shrimp farming is the economic activity with the highest growth rate in the last decade in Mexico. Production of Pacific white shrimp, Litopenaeus vannamei was over $60,000 \mathrm{t}$ during 2004 . From that production, more than $50 \%$ came from the state of Sonora, in Northwestern Mexico (Sagarpa, pers comm.). This explosive development implies the risk of a significant environmental impact by the effluents in the receiving-ecosystems. An inadequate management of feed, feeding practices or discharge strategies, can lead to the discharge of huge amounts of organic matter and nutrients, with the possibility of catastrophic effects to the biota of those ecosystems ${ }^{[1]}$.

Discharge lagoons have been proposed as an alternative to minimize environmental impact of shrimp farming effluents, with the further possibility of using them to culture one or more organisms to provide extra incomes for the farmers. The advantage of this alternative is that organisms in the discharge lagoon do not need supplemental feed, because they fed on the biota (phytoplankton, zooplankton and benthos) developed in the nutrient-enriched effluents and/or on the organic detritus accumulated on the lagoon bottom $^{[2-4]}$.

Nutrition of shrimp farmed semiintensively, depends both on formulated feed and biota in the ponds. Biota is an important source of food for most commercial species of farmed shrimp and may be the main component of their diet ${ }^{[5-7]}$.

Shrimp have benthic habits, except during their first days as larvae and postlarvae. For this reason, benthos have an important role as a source of natural feed in shrimp ponds ${ }^{[8-10]}$.

Many studies on natural aquatic ecosystems and on aquaculture ponds have shown that the main components of shrimp gut are: microcrustaceans, small fish, mollusks, polychaetes, radiolarians, sponges, nematodes, rotifers, copepods, insects, vegetal materials, microalgae, macroalgae, mud and sand $\mathrm{d}^{[7,10,11-}$ ${ }^{16]}$.. However the nutritional contribution of each of these components has not yet been wellestablished ${ }^{[7,15,17]}$. The assessment of that contribution is an important issue in the promotion and maintenance of the most desirable organisms.

\section{Corresponding Author: \\ Dr. Luis R. Martínez Córdova, P.O. Box \\ 1819, Hermosillo, Sonora, 83000, México,} Tel: (052) 662-2592169, Fax: (052) 662-2592197 
Polychaetes have been found to be the main component of the benthic macrofauna in many aquatic ecosystems ${ }^{[18-21]}$. In aquaculture ponds polychaetes are found at high densities in the early weeks, but decline abruptly over the time ${ }^{[22-24]}$. In some shrimp farms, abundance of polychaetes is considered as an indicator of the productivity and availability of natural food in the ponds. It helps farmers decide stocking, feeding and harvest times ${ }^{[25]}$.

The digging activity of polychaetes in the pond bottom resuspend and remineralize organic matter and make nutrients available in the water column ${ }^{[26-28]}$. However, the most important role of polychaeta is to serve as a food source for farmed shrimp. It has been reported that an important proportion of shrimp gut content come from polychaetes ${ }^{[10,29,30]}$.

The objective of the present study was to evaluate the benthic fauna (with especial emphasis on polychaetes) in a discharge lagoon of a shrimp farm, where a secondary culture of shrimp was made and compare it with a pond of the farm. Results can be useful to improve the knowledge about the contribution of that community in the nutrition of farmed shrimp

\section{MATERIALS AND METHODS}

The study was done over sixteen weeks in the facilities of University of Sonora, at Bahía Kino, Sonora and Northwestern Mexico. A discharge lagoon (0.5 ha) of an experimental shrimp farm $(0.3 \mathrm{ha})$ was divided into three sections (A, B and $\mathrm{C}$ ). An experimental ponds $(0.04 \mathrm{ha})$ of the farm, was used as a control. Each lagoon section was stocked with 8000 postlarvae $\left(6 \mathrm{pl} / \mathrm{m}^{2}\right)$ and the experimental pond with 12,800 postlarvae $\left(32 \mathrm{pl} / \mathrm{m}^{2}\right)$. of Pacific white shrimp, Litopenaeus vannamei, obtained from Maricultura del Pacifico Hatchery, at Bahía Kino, Sonora, Mexico. Neither fertilization nor formulated feed was used in the sections of the discharge lagoon. In the pond, shrimp were fed with Camaronina 35 (a formulated feed by Cargill, Ciudad Obregón, Sonora, México) at a rate of $4 \%$ of shrimp biomass per day. Also a fertilization regime consisting of urea and triple super phosphate was applied in the pond at the beginning of the trial and during the farming period when water transparency was greater then $40 \mathrm{~cm}$ in the Sechi disk.

To evaluate the effect of predation of shrimp on the benthic biota, three enclosures were made in the discharge sections and one in the control pond. The enclosures had an area of $4 \mathrm{~m}^{2}$ and were made with plastic net $(0.5 \mathrm{~cm}$ mesh) to keep shrimp out of those areas.

Salinity, temperature, dissolved oxygen and $\mathrm{pH}$ were recorded twice a day (0600 and 1300) in each section and the control pond, using a refractometer, an oxygen meter with temperature sensor and a $\mathrm{pH}$ meter, respectively..

Each two weeks $1 \mathrm{~L}$ of water was taken from each section and the pond to analyze $\mathrm{N}-\mathrm{NO}_{3}, \mathrm{~N}-\mathrm{NO}_{2}$, total ammonium nitrogen (TAN) and $\mathrm{P}_{-} \mathrm{PO}_{4}$ by spectrophotometry, using a Hach DR4000 equipment.

Samples of organic matter in the sediment were taken each two weeks from three points of the sections and the pond with a PVC core sampler $(20.32-\mathrm{cm}$ diameter and $324.3-\mathrm{cm}^{2}$ area), introduced $15-\mathrm{cm}$ depth. The organic matter was analyzed using the ignition method. For organic matter in water $1 \mathrm{~L}$ of pond water was filtered though GFC filters and evaluated by the same method used for sediment.

Benthic organisms was collected similarly as organic matter, but in this case the enclosures were included. The sediment samples were passed through two sieves $(0.5$ and $1.0 \mathrm{~mm})$, to separate organisms by size, following the recommendations of EnríquezOcaña ${ }^{[31]}$ and Nunes and Parsons ${ }^{[30]}$. Material retained in the sieves was examined in a stereomicroscope to separate, identify and count organisms. Identification was made at the level of class and order, except for polychaetes that were identified up to genus or species in some cases, using the keys of Fauchald ${ }^{[32]}$. Drying and weighing all the clean samples using a digital Sartorious balance with a precision of $\pm 0.001 \mathrm{~g}$ determined biomass of organisms.

After verifying data was normal and variance homogeneous, a one way ANOVA was done to detect differences in water and sediment quality variables and in benthic and polychaeta abundance, between sections and ponds and their respective enclosures ${ }^{[33]}$.

\section{RESULTS}

Means and ranges of temperature, salinity, $\mathrm{pH}$, dissolved oxygen, N-NO2, N-NO3, TAN, P-PO4 and organic matter in sediment (OMS) and water (OMW), are shown in Table 1. No differences in any of the first three variables were observed among sections and pond, though they varied widely over time. Temperature increased from the beginning to the middle of the period and then decline slightly. Salinity had an irregular pattern, probably related to tides and the scarce rains in the region. Similarly, the variation of $\mathrm{pH}$ had no defined pattern. Mean dissolved oxygen was higher in the sections as compared to the control pond and in both, varied widely through the farming period without any clear trend.

Significant differences were found in the concentration of N-NO3, TAN, P-PO4 and organic matter, among sections and pond as well as over the time. All the nutrients recorded the highest concentrations in the pond and the lowest in section A. Organic matter was higher in the pond and lower in sections A and B. Nutrients and organic matter do not show a defined pattern over the culture period, although organic matter was higher at the end of the trial (weeks 6 and 7). 
OnLine J. Biol. Sci., 7 (1): 12-17, 2007

Table 1: Means and ranges of water quality parameters in sections and control pond during the study

\begin{tabular}{lllll}
\hline Parameter & Secction A & Section B & Section C & Control Pond \\
\hline Temperature ${ }^{\circ} \mathrm{C}$ & $28.7(26.8-30.6)$ & $28.5(26.7-30.5)$ & $28.8(26.7-30.8)$ & $28.5(27.0-30.2)$ \\
Salinity $(\mathrm{ppt})$ & $44.6(43.1-46.2)$ & $44.7(43.3-46.3)$ & $44.6(43.8-45.6)$ & $44.9(43.9-45.9)$ \\
D.O. $(\mathrm{mg} / \mathrm{L})$ & $3.30(2.90-3.70)$ & $3.27(2.90-3.60)$ & $3.31(2.85-3.75)$ & $2.90(2.58-3.28)$ \\
Ph & $8.56(8.39-8.73)$ & $8.52(8.38-8.71)$ & $8.50(8.37-8.63)$ & $8.66(8.53-8.78)$ \\
N-NO3 $(\mathrm{mg} / \mathrm{L})$ & $1.41(0.6 .-.2 .20) \mathrm{ab}$ & $0.91(0.59-1.65) \mathrm{b}$ & $1.35(0.65-2.0) \mathrm{ab}$ & $1.61(1.10-2.50) \mathrm{a}$ \\
P-PO4 $(\mathrm{mg} / \mathrm{L})$ & $0.54(0.36-0.72) \mathrm{b}$ & $0.67(0.45-0.87) \mathrm{b}$ & $0.75(0.51-1.05) \mathrm{c}$ & $0.75(0.55-1.02) \mathrm{c}$ \\
TAN $(\mathrm{mg} / \mathrm{L})$ & $0.10(0.03-0.08) \mathrm{a}$ & $0.14(0.02-0.45) \mathrm{a}$ & $0.23(0.05-0.2) \mathrm{ab}$ & $0.39(0.15-0.7) \mathrm{b}$ \\
OMS $(\%)$ & $2.58(1.71-3.52) \mathrm{a}$ & $2.16(1.44-3.02) \mathrm{a}$ & $2.43(1.55-2.40) \mathrm{a}$ & $2.85(2.01-3.70) \mathrm{a}$ \\
OMW $(\%)$ & $1.67(0.62-2.81) \mathrm{a}$ & $1.98(0.61-3.50) \mathrm{a}$ & $1.44(0.81-2.00) \mathrm{a}$ & $2.10(1.26-3.0 \mid) \mathrm{a}$ \\
\hline
\end{tabular}

D.O. = Dissolved Oxygen; TAN = Total ammonium nitrogen; OMS = Organic matter in sediment; OMW = Organic matter in water column

Table 2: Abundance of the main benthic groups during the eight samplings in discharge sections, control ponds and enclosures

\begin{tabular}{|c|c|c|c|c|c|c|c|c|c|c|}
\hline Sections & Groups & $\begin{array}{l}\text { Sampling } \\
1\end{array}$ & $\begin{array}{l}\text { Sampling } \\
2\end{array}$ & $\begin{array}{l}\text { Sampling } \\
3\end{array}$ & $\begin{array}{l}\text { Sampling } \\
4\end{array}$ & $\begin{array}{l}\text { Sampling } \\
5\end{array}$ & $\begin{array}{l}\text { Sampling } \\
6\end{array}$ & $\begin{array}{l}\text { Sampling } \\
7\end{array}$ & $\begin{array}{l}\text { Sampling } \\
8\end{array}$ & Totals \\
\hline \multirow[t]{4}{*}{ Section A } & Chironomidae & $231 \pm 69$ & $216 \pm 80$ & $262 \pm 85$ & $406 \pm 69$ & $442 \pm 175$ & $458 \pm 63$ & $612 \pm 45$ & $494 \pm 138$ & 3121 \\
\hline & Gammaridea & $52 \pm 51$ & $31 \pm 18$ & 0 & 0 & 0 & 0 & 0 & 0 & 83 \\
\hline & Cerithidia sp. & 0 & 0 & 0 & 0 & 0 & 0 & $31 \pm 18$ & $51 \pm 10$ & 82 \\
\hline & Polydora socialis & $72 \pm 7$ & $182 \pm 45$ & $238 \pm 24$ & $161 \pm 41$ & $486 \pm 37$ & $495 \pm 51$ & $226 \pm 26$ & $616 \pm 30$ & 2476 \\
\hline \multirow[t]{4}{*}{ Enclosure A } & Chironomidae & $308 \pm 118$ & $231 \pm 62$ & $226 \pm 80$ & $360 \pm 96$ & $391 \pm 111$ & $596 \pm 54$ & $591 \pm 109$ & $524 \pm 62$ & 3227 \\
\hline & Gammaridea & $30 \pm 18$ & 0 & $21 \pm 10$ & 0 & 0 & 0 & 0 & 0 & 81 \\
\hline & Cerithidia sp. & 0 & 0 & 0 & 0 & 0 & 0 & $51 \pm 27$ & $82 \pm 10$ & 133 \\
\hline & Polydora socialis & $871 \pm 11$ & $170 \pm 14$ & $245 \pm 19$ & $442 \pm 36$ & $792 \pm 40$ & $743 \pm 106$ & $777 \pm 51$ & $701 \pm 89$ & 3941 \\
\hline \multirow[t]{4}{*}{ Section B } & Chironomidae & $123 \pm 71$ & $82 \pm 27$ & $195 \pm 75$ & $432 \pm 64$ & $391 \pm 94$ & $478 \pm 146$ & $581 \pm 113$ & $591 \pm 94$ & 2873 \\
\hline & Gammaridea & $31 \pm 18$ & 0 & 0 & 0 & 0 & 0 & 0 & 0 & 31 \\
\hline & Cerithidia sp. & 0 & 0 & 0 & 0 & 0 & 0 & $22 \pm 20$ & $134 \pm 57$ & 135 \\
\hline & Polydora socialis & $89 \pm 15$ & $188 \pm 15$ & $195 \pm 37$ & $239 \pm 20$ & $566 \pm 25$ & $558 \pm 28$ & $277 \pm 36$ & $206 \pm 90$ & 2318 \\
\hline \multirow[t]{4}{*}{ Enclosure B } & Chironomidae & $303 \pm 67$ & $98 \pm 44$ & $565 \pm 107$ & $386 \pm 96$ & $504 \pm 31$ & $391 \pm 125$ & $473 \pm 121$ & $550 \pm 86$ & 3270 \\
\hline & Gammaridea & $31 \pm 18$ & $10 \pm 10$ & $21 \pm 20$ & 0 & 0 & 0 & 0 & 0 & 61 \\
\hline & Cerithidia sp. & 0 & 0 & 0 & 0 & 0 & 0 & $62 \pm 18$ & $134 \pm 37$ & 196 \\
\hline & Polydora socialis & $55 \pm 12$ & $171 \pm 46$ & $253 \pm 70$ & $384 \pm 54$ & $713 \pm 197$ & $745 \pm 255$ & $709 \pm 202$ & $505 \pm 145$ & 3532 \\
\hline \multirow[t]{4}{*}{ Section C } & Chironomidae & $245 \pm 120$ & $108 \pm 73$ & 406. \pm 42 & $447 \pm 67$ & $545 \pm 63$ & $494 \pm 147$ & $576 \pm 115$ & $545 \pm 72$ & 3366 \\
\hline & Gammaridea & $21 \pm 20$ & $10 \pm 10$ & 0 & 0 & 0 & 0 & 0 & 0 & 31 \\
\hline & Cerithidia sp. & 0 & 0 & 0 & 0 & 0 & 0 & $31 \pm 18$ & $93 \pm 18$ & 124 \\
\hline & Polydora socialis & $130 \pm 12$ & $113 \pm 16$ & $236 \pm 80$ & $311 \pm 18$ & $576 \pm 115$ & $537 \pm 61$ & $635 \pm 307$ & $143 \pm 52$ & 2681 \\
\hline \multirow[t]{4}{*}{ Enclosure C } & Chironomidae & $195 \pm 81$ & $211 \pm 59$ & $355 \pm 125$ & $329 \pm 71.42$ & $494 \pm 53$ & $571 \pm 67$ & $540 \pm 85$ & $658 \pm 54$ & 3353 \\
\hline & Gammaridea & $21 \pm 20$ & 0 & $21 \pm 21$ & 0 & 0 & 0 & 0 & 0 & 41 \\
\hline & Cerithidia sp. & 0 & 0 & 0 & 0 & 0 & 0 & $113 \pm 27$ & $93 \pm 47$ & 206 \\
\hline & Polydora socialis & $104 \pm 10$ & $152 \pm 32$ & $319 \pm 75$ & $450 \pm 100$ & $951 \pm 68$ & $924 \pm 49$ & $761 \pm 90$ & $750 \pm 63$ & 4006 \\
\hline \multirow[t]{4}{*}{ Control Pond } & Chironomidae & $231 \pm 79$ & $129 \pm 31$ & $416 \pm 167$ & $427 \pm 49$ & $550 \pm 86$ & $560 \pm 89$ & $504 \pm 140$ & $565 \pm 89$ & 3382 \\
\hline & Gammaridea & $51 \pm 37$ & $11 \pm 10$ & 0 & 0 & 0 & 0 & 0 & 0 & 62 \\
\hline & Cerithidia sp. & 0 & 0 & 0 & 0 & 0 & 0 & $103 \pm 27$ & $72 \pm 45$ & 195 \\
\hline & Polydora socialis & $74 \pm 6$ & $110 \pm 23$ & $281 \pm 21$ & $318 \pm 40$ & $345 \pm 51$ & $408 \pm 36$ & $111 \pm 27$ & $50 \pm 9$ & 1697 \\
\hline \multirow[t]{4}{*}{ Enclosure pond } & Chironomidae & $170 \pm 32$ & $216 \pm 90$ & $252 \pm 119$ & $504 \pm 49$ & $411 \pm 147$ & $555 \pm 94$ & $565 \pm 76$ & $494 \pm 158$ & 3167 \\
\hline & Gammaridea & $11 \pm 10$ & $31 \pm 18$ & 0 & 0 & 0 & 0 & 0 & 0 & 42 \\
\hline & Cerithidia sp. & 0 & 0 & 0 & 0 & 0 & 0 & $144 \pm 10$ & $144 \pm 67$ & 288 \\
\hline & Polydora socialis & $s 104 \pm 16$ & $154 \pm 18.30$ & $202 \pm 54$ & $529 \pm 45$ & $732 \pm 58$ & $856 \pm 73$ & $690 \pm 83$ & $119 \pm 18$ & 3386 \\
\hline
\end{tabular}

The main groups identified in the benthic fauna were: insects of the family Chironomidae, crustaceans of the order Amphipoda, mollusks of the class Gastropoda and the polychaete Polydora socialis. By predominance, insects $(63 \%)$ and polychaetes $(34 \%)$ were the most important, whereas mollusks and amphipods were present with a frequency of only $2 \%$ and $1 \%$.

A total of 4,936 benthic organisms were collected during the experiment; 2,511 insect larvae, 2,226 polychaetes worms, 125 gastropods and 74 amphipods. Table 2 shows the density of the main groups found by sampling in each of the sections and the control pond and in their respective enclosures. Table 3 summarizes the abundance of total benthic fauna and total polychaetes by $\mathrm{m}^{2}$ of the bottom. Significant differences in total benthic fauna were found among sections and the pond with the greatest value recorded in section $\mathrm{C}$ and the lowest in the control pond. Density was lower in sections and pond as compared with their respective enclosures. Enclosure of section $\mathrm{C}$ recorded the greatest total benthic density.

Abundance of polychaetes was higher in all the sections as compared to the control pond, with the highest values in sections $\mathrm{B}$ and $\mathrm{C}$ and the lowest in the pond. The abundance was always lower in all sections 
and the pond than in their respective enclosures. Among the enclosures the greatest abundance was found in enclosures of sections $\mathrm{C}$ and $\mathrm{A}$ and the lowest in the enclosure of the control pond. Abundance of polychaetes in sections, pond and enclosures, showed an increase from the beginning of the trial up to weeks 4 and 5 and then a decrease to the end of the trial. The decrease was much more abrupt in the sections than in the respective enclosures.

Table 3: Abundance of total benthic fauna and polychaeta in the sections, control and their respective enclosures

\begin{tabular}{lll}
\hline Sections & Total benthic fauna $/ \mathrm{m}^{2}$ & Polychaeta $/ \mathrm{m}^{2}$ \\
\hline Section A & $5762^{\mathrm{a}}$ & $2476^{\mathrm{a}}$ \\
Enclosure A & $7382^{\mathrm{c}}$ & $3941^{\mathrm{bc}}$ \\
Section B & $5657^{\mathrm{ab}}$ & $2318^{\mathrm{a}}$ \\
Enclosure B & $7059^{\mathrm{bc}}$ & $3532^{\mathrm{b}}$ \\
Section C & $6202^{\mathrm{ab}}$ & $2681^{\mathrm{a}}$ \\
Enclosure C & $7606^{\mathrm{c}}$ & $4006^{\mathrm{c}}$ \\
Pond & $5336^{\mathrm{a}}$ & $1697^{\mathrm{a}}$ \\
Enclosure pond & $688^{2}$ & $3386^{\mathrm{b}}$ \\
\hline Values in column & with different & superscript were significantly \\
different $(\mathrm{P}<0.05)$ & &
\end{tabular}

\section{DISCUSSION}

The lower values of dissolved oxygen in the pond, compared to the discharge sections is attributed to the higher density of shrimp and consequently a greater respiration rate, as has been reported in previous studies in this region and other ${ }^{[7,24]}$.

A wide variation in temperature, salinity and $\mathrm{pH}$ was measured in the discharge sections and in the control pond. This probably had a significant effect on the abundance and composition of benthic fauna. Groups such as amphipods were present only when environmental conditions were adequate for their development. Polychaeta is a more resistant group and were present during the entire period, although with variations in their density produced by other factors.

Feeding and fertilization in the control pond caused it to have a higher concentration of nutrients and organic matter than the discharge sections. The variation of organic matter through the farming period seems to be related not only to feeding and fertilization, but also to the density of benthic fauna, especially polychaetes that consume detritus directly ${ }^{[26]}$.

Polychaetes were the second most abundant group in the sections and pond, as found in many other aquatic ecosystems. The abundance of this group in sections and ponds increased during the first weeks and then declined abruptly up to the end of the trial, agreeing with that reported by Martinez-Cordova et $a l .{ }^{[24]}$. The decrease was mostly caused by the predation of shrimp, which increases proportionally to its biomass. This is confirmed by two facts; 1) the much greater abundance of polychaetes in the sections, where shrimp density was low (6org $/ \mathrm{m} 2)$, as compared to the control pond where shrimp density was high (32 org $/ \mathrm{m} 2$ ) and 2) the much lower abundance and more abrupt decrease of polychaetes in the sections and the ponds where shrimp were present, compared to their corresponding enclosures where shrimp were absent. Similar results were reported by Nunes et al. ${ }^{[25]}$.

Penaeid shrimp can efficiently consume polychaetes from their juvenile to adult stages ${ }^{[10,15,25]}$ and their consumption rate increases with the size of shrimp ${ }^{[7,17,19,34,35]}$. Nunes and Parsons ${ }^{[21]}$ working with L. schmitti reported that abundance and biomass of shrimp were proportional to shrimp density and the amount of formulated feed supplied. Their abundance increased with the augmentation of organic detritus but only up to a shrimp density lower than 20 organisms $/ \mathrm{m} 2$.

\section{CONCLUSION}

From the results of the present study, it can be concluded that a few groups, with insects and polychaetes as the most abundant, dominate the benthic fauna in shrimp ponds and discharge lagoons. Abundance and biomass of polychaetes are regulated by the concentration of organic detritus but mostly by the density of shrimp. Litopenaeus vannamei efficiently consumes polychaetes and when these organisms are present in the ponds or discharge lagoons, constitute the main food source of the shrimp, as reported by Martínez et al. ${ }^{[36]}$.

\section{ACKNOWLEDGEMENTS}

We want to thank Conacyt (The Mexican Council of Science and Technology) for the financial support to this project. Also Alfredo Campaña Torres and Isidro Vazquez Salgado for their technician support.

\section{REFERENCES}

1. Anon., 1993. Shrimp farm revage the environment and people in Bangladesh. World Shrimp Farming, 18: 8-9.

2. Martínez-Córdova, L., R. Barraza and F. Enriquez, 1992. Biculture of shrimp and clams in ponds in Sonora, México (Fall-Winter season). J. Aquacult. Trop., 7: 47-52. 
3. Martínez-Córdova, L., H. Villarreal-Colmenares and M. Porchas-Cornejo, 1995. Culture of white shrimp Penaeus vannamei in reduced water exchange ponds in Sonora, México. World Aquacul., 26: 47-48.

4. Martínez-Córdova, L., H. Villarreal-Colmenares and M. Porchas-Cornejo, 1996. Culture of white shrimp Peneus vannamei (without food in a discharge lagoon of a shrimp farm. World Aquacult., 27: 68-69.

5. Reymond, H. and J.P. Lagardère, 1990. Feeding rhythms and food of Penaeus japonicus Bate (Crustacea, Penaeidae) in salt water pond: Role of halophilic entomofauna. Aquaculture, 81: 125-143.

6. Focken, U., A. Groth, R.M. Coloso and K. Becker, 1998. Contribution of natural food and supplemental feed in the gut content of Penaeus monodon Fabricius in a semi-intensive pond system in the Philippines. Aquaculture, 164: 105116.

7. Martínez-Córdova, L., N. Pasten and R. BarrazaGuardado, 1998. Effect on growth, survival, food conversion ratio and production of Pacific white shrimp Penaeus vannamei in earthen ponds in Sonora, Mexico. The Progressive Fish-Culturist, 60: 101-108.

8. Allan, G.L., J.W. Moriarty and G.B. Maguire, 1995. Effect of pond preparation and feeding rate on production of Penaeus monodon Fabricius in model farming ponds. Aquaculture, 130: 329-349.

9. Hendrickx, M.E., J.S. Barragán and M.A. Martínez, 1996. Abundance and diversity of macrofauna (fish and decapod crustaceans) in Penaeus vannamei culture ponds in Western Mexico. Aquaculture, 143: 61-73.

10. Martinez-Cordova, L. and E. Peña-Messina, 2005. Biotic communities and feeding habits of Litopenaeus vannamei (Boone, 1931) and L. stylirostris (Stimpson, 1974) in monoculture and polyculture semi-intensive ponds. Aquacult. Res., 36: 1075-1084.

11. Thomas, M.M., 1992. Food and feeding habits of Penaeus monodon from Kirapuzha estuary. Ind. J. Fish., 19: 202-204

12. Rubright, J.S., J. Harell, L. Holcomb and J.C. Parker, 1981. Responses of planktonic and benthic communities to fertilizer and feed applications in shrimp mariculture ponds. J. World Aquacult. Soc., 12: 281-299.
13. Marte, C.L., 1982. Seasonal variation in food and feeding of Penaeus monodon Fabricius (Decapoda, Natantia). Crustaceana, 42: 225-255.

14. Su, M.S. and I.C. Liao, 1986. Distribution and Feeding Ecology of Penaeus monodon along the Coast Tungkung, Taiwan. In The First Asian Fisheries Forum (Eds. JlL. Maclean, L.B. Dizon and L. V. Kosilloos), pp: 207-210. Manila, Philippines.

15. Dall, W., B.J. Hill, P.C. Rothlisberg and D.J. Sharples, 1990. The biology of the Penaeidae. Advances in Marine Biology, Vol. 27. Academic Press. San Diego Ca, USA.

16. Mertens, J., N. Munuswamy, C.D. Walsche and H.J. Dumont, 1990. On predatory tendencies in the feeding ecology of the fairy shrimp Streptocephalus proboscideus (Frauenfeld, 1873). Hydrobiologia, 198: 119-123.

17. Shishehchian, F. and F.M. Yusoff, 1999. Composition and abundance of macrobenthos in intensive tropical marine shrimp culture ponds. J. World Aquacult. Soc., 30: 128-133.

18. Maguire, G.B., P.J. Gibbs and L.C. Collett, 1984. The macrobenthic fauna of brackish water prawn farming ponds at Port Stephens. New South Wales. Aust. Zool., 21: 445-458.

19. Ordner, M.T. and A.L. Lawrence, 1987. Importance of Polychaeta to Penaeid Pond Culture. In: Abstracts of the 18th Annual Meeting of the World Aquaculture Society, 18-23 January, 1987, Guayaquil, Ecuador. J. World Aquacult. Soc., pp: 36A-37A.

20. Barraza-Guardado, R., 1996. Estudio de los principales componentes de la productividad natural en estanques durante la preengorda de Penaeus vannamei Boone, 1931. Tesis de Maestría. Departamento de Investigaciones Científicas y Tecnológicas de la Universidad de Sonora. Hermosillo, Sonora, México, pp: 124.

21. Nunes, A.J.P. and G.J. Parsons, 1999. Feeding levels of the southern brown shrimp Penaeus subtilis in response to food disperseal. J. World Aquacult. Soc., 29: 27-37.

22. Crockett, J., L. Sturmer, A. Lawrence and J. Whitson, 1988. Polychaeta biomass as an indicator of natural productivity in penaeid shrimp culture ponds. 24-25a. In: Abstracts of the 19th Annual Meeting of the Worm Aquaculture Society, 2-9 January 1988, Honolulu, USA. J. World Aquacult. Soc., 19. 
23. Martínez-Córdova, L., H. Villarreal-Colmenares, M. Porchas-Cornejo, J. Naranjo-Paramo and A. Aragon-Noriega, 1997. Effect of aeration rate on growth, survival and yield of white shrimp $P$. vannamei in reduced water exchange ponds. Aquacult. Engg., 16: 85-90.

24. Martínez-Córdova, L., M. Porchas-Cornejo, H. Villarreal-Colmenares, J. Calderón-Pérez and J. Naranjo-Páramo, 1998b. Evaluation of three feeding strategies on the culture of white shrimp Penaeus vannamei Bonne 1931 in low water exchange ponds. Aquacult. Engg., 17: 21-28.

25. Nunes, A.J.P., T.C. Gesteira and S. Goddard, 1977. Food ingestion and assimilation by the Southern brown shrimp Penaeus subtilis under semiintensive culture in NE Brazil. Aquaculture, 149: 121-136.

26. Heilskov, A. and M. Holmer, 2001. Effects of benthic fauna on organic matter mineralization in fish-farmed sediments: Importance of size and abundance. ICES J. Marine Sci., 58: 427-434.

27. Madsen, S.D., T.L. Forbes and V.E. Forbes, 1997. Particle mixing by the polychaeta Capitella species: I. Coupling fate and effect of a particlebound organic contaminated (flouranthene) in a marine sediment. Marine Ecol. Prog. Ser., 147: 129-142.

28. Mayer, M.S., L. Schaffner and W.M. Kemp, 1995. Nitrificartion pontentials of benthic macrofaunal tubes and burrow walls: Effects of sediment NH4+ and animal irrigation behavior. Marine Ecol. Prog. Ser., 121: 157-169.
29. Boddeke, R., 1983. Survival Strategies of Penaeid Shrimps and their Significance for Shrimp Culture. In: Proc. First Intl. Conf. Warmwater Aquaculture. (Eds. Roger, G.L., Day, R., Lim, A), pp: 514-523 11, Lpuisiana, USA.

30. Nunes, A.J.P. and G.J. Parsons, 2000. Effects of the Southern brown shrimp, Penaeus subtilis, predation and artificial feeding on the population dynamics of benthic polychaetes in tropical pond enclosures. Aquaculture, 183: 125-147.

31. Enríquez-Ocaña, L.F., 1999. Estudio de la variación temporal y espacial de los poliquetos (Annelida:Polichaeta) de la Bahía Las Guásimas, Sonora. Bachelor Thesis Universidad Nacional Autónoma de México. México, D.F., pp: 82.

32. Fauchald, K., 1977. The polychaeta worms, definitions and keys to the orders, families and genera. Natural History Museum. Los Angeles City. Scientific Series, 28: 1-190.

33. Zar, H., 1999. Biostatistical Análisis. Prentice-Hall. New Jersey. USA, pp: 663.

34. Chesney, E.J.Jr and K.M. Tenore, 1985. Effects of predation and disturbance on the population growth and dynamics of the polychaete, Capitella capitata (Type I). Marine Biol., 85: 77-82.

35. Tsutsumi, H., 1987. Population dynamics of Capitella capitata (Polychaeta:Capitellidae) in an organically polluted cove. Marine Ecol. Prog. Ser., 36: 139-149.

36. Martínez-Córdova, L.R. and M.A. Porchas Cornejo, 1999. Engorda de camarones peneidos. In: Cultivo de Camarones Peneidos, Principios y Prácticas, (Ed. Martínez-Córdova, L.R), pp: 105143, AGT Editor. México, D.F. 